Proc. Estonian Acad. Sci. Geol., 1997, 46, 3, 146-149

\title{
ARE ALL SPECIES OF THE MAIN DEVONIAN FIELD ASSIGNED TO THE GENUS Ripidiorhynchus SARTENAER, P., 1966 VALID?
}

\author{
Paul SARTENAER
}

Institut royal des Sciences naturelles de Belgique, rue Vautier 29, B-1000 Bruxelles, Belgium

Received 3 February 1997, accepted 9 June 1997

KAS KÕIK PEADEVONIVÄLJAL ESINEVAD Ripidiorhynchus SARTENAER, P., 1966 LIIGID ON VALIIDSED? Paul SARTENAER

ВСЕ ЛИ ВИДЫ Ripidiorhynchus SARTENAER, Р., 1966, РАСПРОСТРАНЕННЫЕ НА ГЛАВНОМ ДЕВОНСКОМ ПОЛЕ, ВАЛИДНЫЕ? ПОЛЬ САРТЕНЕР

Key words: Devonian, brachiopods, East European Platform.

Nalivkin (1941, pp. 158-161, 203-204) included within the "group of Camarotoechia livonica Buch" four new species from the Main Devonian Field (East European Platform): C. aldoga, C. pskovensis, C. strugi, and C. tschudovi. He did not otherwise mention C. livonica (von Buch, 1834).

In January 1964, in Leningrad, when the author asked Academician D. V. Nalivkin why he did not redescribe C. livonica, he answered that the loss of the type series prevented him to do it. It was obvious both to D. V. Nalivkin and the author that one of the four species would become a junior synonym of C. livonica as soon as the type series would be "rediscovered".

Shortly after this visit the author located the type series in the "Institut für Paläontologie und Museum der math.-naturwissenschaftlichen Fakultät der Humboldt Universität zu Berlin". This allowed him to erect the genus 
Ripidiorhynchus Sartenaer, P., 1966 with $R$. livonicus as the type species. In choosing the long-standing central Latvian species as the type species, the author wanted to avoid to discuss the validity of the four species mentioned above and to prevent any disruption of stability of nomenclature in the future. The choice carried with it the disadvantage that no more than just Frasnian could be said for the age of the species and the author was obliged to write (Sartenaer, 1966, p. 12) that it was the task of regional geologists to fix a more precise age. This is what Sorokin (1978) very ably did, and we know now that $R$. livonicus has a lower Frasnian age (for stratigraphical nomenclature used see the figure).

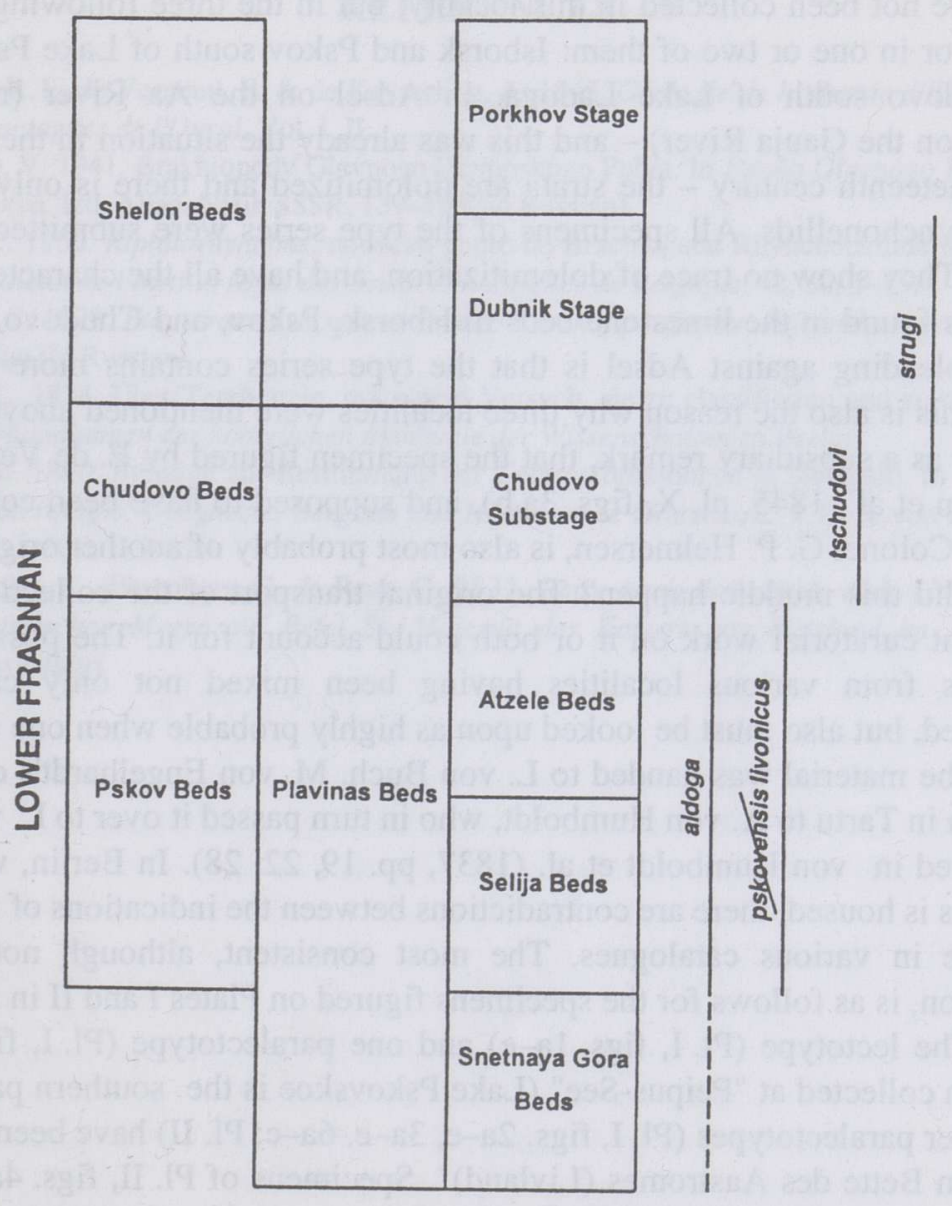

Stratigraphical range of the species discussed in the present note. Remark: Ripidiorhynchus strugi has rarely been mentioned as early as in the Atzele Beds, and R. tschudovi as late as in the Dubnik Stage. 
Von Buch (1834, p. 38) wrote about the material of Terebratula livonica at his disposal: "Aus Mittel-Liefland, durch Herrn von Engelhardt gefunden bei Adsel am Bette des Aastromes in einer Schicht von weissem, dichten Kalkstein, in welchem diese Terebratel in grosser Menge vereinigt vorkommt... Es ist nicht deutlich zu welcher Formation dieser Kalkstein gezählt werden könne..." Later he added: "Sie ist nicht Liefland allein eigen, sondern findet sich auch, und in Menge, dem Waldai viel näher bei Isborsk, West von Pleskow..." (von Buch, 1840, p. 61).

Although this should leave no doubt about Adsel being the locus typicus of the species, the purpose of this note is to demonstrate that the specimens of the type series have not been collected in this locality, but in the three following Russian localities or in one or two of them: Isborsk and Pskov south of Lake Pskovskoe, and Chudovo south of Lake Ladoga. In Adsel on the Aa River (nowadays Gaujiena on the Gauja River) - and this was already the situation in the first half of the nineteenth century - the strata are dolomitized and there is only one bed rich in rhynchonellids. All specimens of the type series were submitted to close scrutiny. They show no trace of dolomitization, and have all the characteristics of specimens found in the limestone beds in Isborsk, Pskov, and Chudovo. Another element pleading against Adsel is that the type series contains more than one species; this is also the reason why three localities were mentioned above. It must be added, as a subsidiary remark, that the specimen figured by E. de Verneuil (in Murchison et al., 1845, pl. X, figs. 3a,b), and supposed to have been collected in Adsel by Colonel G. P. Helmersen, is also most probably of another origin.

How did this muddle happen? The original transport of the collection or the subsequent curatorial work on it or both could account for it. The possibility of specimens from various localities having been mixed not only cannot be disregarded, but also must be looked upon as highly probable when one considers the way the material was handed to L. von Buch. M. von Engelhardt's collection was given in Tartu to A. von Humboldt, who in turn passed it over to L. von Buch as indicated in von Humboldt et al. (1837, pp. 19, 22, 28). In Berlin, where the type series is housed, there are contradictions between the indications of the labels and those in various catalogues. The most consistent, although not reliable information, is as follows for the specimens figured on Plates I and II in Sartenaer (1966). The lectotype (Pl. I, figs. 1a-e) and one paralectotype (Pl. I, figs. 7a-c) have been collected at "Peipus-See" (Lake Pskovskoe is the southern part of this lake); other paralectotypes (Pl. I, figs. 2a-e, 3a-e, 6a-c; Pl. II) have been found in "Adsel am Bette des Aastromes (Livland)". Specimens of Pl. II, figs. 4a-e, 5a-e are hypotypes and come from "Pleskow" (= Pskov).

It is fortunate that the lectotype of Ripidiorhynchus livonicus allows us to overcome the technical problems, and to answer the question raised at the beginning of this note: which of the four species proposed by Nalivkin (1941) has to be dropped? He wrote $(1941$, pp. 157,203$)$ that "all these species... are in a close affinity, and are frequently linked by transitions, but when found in ample 
quantities may be easily distinguished from each other and serve as guide forms". The following characters of the lectotype of Ripidiorhynchus livonicus indicate that $R$. pskovensis is the species that is the junior synonym of $R$. livonicus: a very high tongue; high and acute median costae strongly indenting the upper part of the tongue; and the number of costae. These characters are those used by Nalivkin (1941, pp. 159, 203) to separate $R$. pskovensis from $R$. strugi.

The door is now open for solving various taxonomic problems. In particular, what is the name to be given to the species found in Adsel?

\section{REFERENCES}

Murchison, R. I., de Verneuil, E. \& de Keyserling, A. 1845. Géologie de la Russie d'Europe et des montagnes de l'Oural. Vol. I, II.

Nalivkin, D. V. 1941. Brakhiopody Glavnogo Devonskogo Polya. In Fauna Glavnogo Devonskogo Polya. Izd. Akad. Nauk SSSR, 139-195 (in Russian).

Sartenaer, P. 1966. Ripidiorhynchus, nouveau genre de Brachiopode Rhynchonellide du Frasnien. Bulletin de l'Institut royal des Sciences naturelles de Belgique, 42, 30, 1-15.

Sorokin, V. S. 1978. Etapy razvitiya severo-zabada Russkoj platformy vo franskom veke. Zinātne, Rīga (in Russian).

von Buch, L. 1834. Über Terebrateln, mit einem Versuch, sie zu classificiren und zu beschreiben. Abhandlungen der königlichen Akademie der Wissenschaften zu Berlin.

von Buch, L. 1840. Beiträge zur Bestimmung der Gebirgsformationen in Russland. In Archiv für Mineralogie, Geognosie, Bergbau und Hüttenkunde (Karsten, C. J. B. \& von Dechen, H., eds.), $\mathbf{X V}, 1,3-128$.

von Humboldt, A., Ehrenberg, G. \& Rose, G. 1837. Reise nach dem Ural, dem Altai und dem Kaspischen Meere auf Befel Sr. Majestät des Kaisers von Russland im Jahre 1829 ausgeführt. 